\title{
Comparative effects of dry-aging and wet-aging on physicochemical properties and digestibility of Hanwoo beef
}

\author{
Ji-Han Kim 1,a , Tae-Kyung Kim 2,a , Dong-Min Shin', Hyun-Wook Kim³, \\ Young-Boong Kim², and Yun-Sang Choi ${ }^{2, *}$
}

\author{
* Corresponding Author: Yun-Sang Choi \\ Tel: +82-63-219-9387, Fax: +82-63-219-9076 \\ E-mail: kcys0517@kfri.re.kr \\ 1 Department of Food Science and Biotechnology of \\ Animal Resources, Konkuk University, Seoul 05029, \\ Korea \\ 2 Research Group of Food Processing, Korean Food \\ Research Institute, Wanju 55365, Korea \\ ${ }^{3}$ Department of Animal Science and Biotechnology, \\ Gyeongnam National University of Science and \\ Technology, Jinju 52725, Korea \\ a The author contributed equally to this work. \\ ORCID \\ Ji-Han Kim \\ https://orcid.org/0000-0001-8197-0612 \\ Tae-Kyung Kim \\ https://orcid.org/0000-0002-6349-4314 \\ Dong-Min Shin \\ https://orcid.org/0000-0003-2755-433X \\ Hyun-Wook Kim \\ https://orcid.org/0000-0002-4397-9664 \\ Young-Boong Kim \\ https://orcid.org/0000-0001-8441-198X \\ Yun-Sang Choi \\ https://orcid.org/0000-0001-8060-6237
}

Submitted Jan 11, 2019; Revised May 27, 2019; Accepted Jun 20, 2019
Objective: The purpose of this study was to investigate the effects of aging methods (AM) i.e. dry-aging (DA) and wet-aging (WA) on the physicochemical properties and in vitro digestibility of proteins in beef short loin.

Methods: Short loins (M. longissmus lumborum), were trimmed and boned-out on the fifth day postmortem, from a total of 18 Hanwoo, which were purchased from a commercial slaughterhouse. Short loins were separated randomly grouped into one of the three treatments: control, WA $\left(1^{\circ} \mathrm{C}, 7\right.$ days $)$, and DA $\left(1^{\circ} \mathrm{C}, 0.5 \mathrm{~m} / \mathrm{s}, 85 \%\right.$ relative humidity $[\mathrm{RH}], 30$ days).

Results: Dry-aged beef (DAB) exhibited higher pH, water holding capacity (WHC), myofibrillar fragmentation index (MFI), and digestibility, however lower lightness, redness, and yellowness values, cooking loss, and shear force (SF), than those of wet-aged beef (WAB) $(p<0.05)$. The myosin light chain band intensity of DAB was higher than that of control and WAB in sodium dodecyl sulfate-polyacrylamide gel electrophoresis. The in vitro digestibility of aged beef was highly $(\mathrm{p}<0.001)$ correlated to physicochemical properties except WHC. The correlation coefficient between AMs and WHC was higher than that between AM and $\mathrm{SF}(\mathrm{p}<0.05)$ or MFI $(\mathrm{p}<0.001)$. A high correlation was observed between SF and MFI $(\mathrm{p}<0.001)$. Conclusion: Thus, we believe that DAB is more advantageous than WAB owing to its high digestibility and WHC and low SF.

Keywords: Wet Aging; Dry Aging; Digestibility; Shear Force; Beef Loin

\section{INTRODUCTION}

Meat quality is a very important aspect to the consumers and the meat industry. In fact, the most important factors of beef quality are tenderness and juiciness. Therefore, in accordance with the consumer preferences, a high-marbling attribute has a positive impact on the palatability of beef [1]. However, to be preferred, the low-marbled beef needs to be improved in various ways to improve its poor taste, toughness, and dryness. Various efforts are being taken up by mainly using mechanical methods to improve the palatability of lowmarbled beef [2].

Aging is another approach used to improve the tenderness, flavor, and juiciness i.e. water holding capacity (WHC) of beef and is recently being used to improve low-marbled products. Yim et al [3] reported that aging method (AM) is being widely used to improve the meat tenderness and juiciness, by causing complex changes in the muscle metabolism. The $\mathrm{AM}$ is utilized to enhance the tenderness and aid in flavor development of beef products. Aging is normally processed through either wet-aging (WA) or dry-aging (DA) [4]. The WA is more commonly used and refers to allowing meat to age by storing it in a sealed barrier package such as vacuum package at refrigerated temperatures for up to 7 days [5]. The DA 
is an expensive procedure that needs a lot of space and time. It causes a significant level of shrinkage and generates a high amount of crust with excessively dried wastes that must be trimmed [1]. The dry-aged beef (DAB) had higher trim loss than wet-aged beef (WAB) [6]. Moreover, the storage of DAB is relatively expensive compared to WAB because of the shrinkage and wastage of beef directly related to the $\mathrm{DAB}$ procedure [7]. Smith et al [5] reported that DAB is a successful process and is used at special outlets to meet the needs of consumers who prefer this unique beef flavor. A few researchers have studied the variations in the characteristics of WAB and $D A B$ with respect to their quality [1,5-8]. Furthermore, studies were conducted on the quality variations between WA and DA processes $[4,6]$. However, regarding digestibility, the comparison between $\mathrm{WAB}$ and $\mathrm{DAB}$ and correlation studies remain unexplored.

Therefore, the objectives of this study were to understand the influence of AM on the digestibility and correlation between the type of AM and physicochemical properties of beef.

\section{MATERIALS AND METHODS}

\section{Samples preparation and aging methods}

Short loins (M. longissmus lumborum), were trimmed and boned-out on the 5 days postmortem, from a total of 18 Hanwoo (quality grade 1, approximately 26 month age), which were purchased from a commercial slaughterhouse. Short loins were separated randomly grouped into one of the three treatments: control, WA $\left(1^{\circ} \mathrm{C}, 7\right.$ days $)$, and DA $\left(1^{\circ} \mathrm{C}\right.$, $0.5 \mathrm{~m} / \mathrm{s}, 85 \%$ relative humidity [RH], 30 days) [9]. Each side was equally represented among the aging treatments. Each loin section was relocated within the individual testing chambers on weekly basis to avoid any location effect on meat quality attributes. Each short loin designated for WA was weighed in a vacuum package and placed in cooler on a stainless-steel rack. The Hanwoo loin sections were removed from the assigned aging test chamber. The loss in weight and time taken for surface trimming were recorded. Steak samples were cut from each loin section to assess the meat physicochemical properties and perform digestibility analyses. All the processes were performed in triplicates.

\section{Cooking methods}

Samples were placed at room temperature $\left(20^{\circ} \mathrm{C}\right)$ for $30 \mathrm{~min}$ prior to cooking and cut into cubes $(3 \times 3 \times 2.54 \mathrm{~cm}$, diameter $\times$ diameter $\times$ thickness). The samples were cooked at $145^{\circ} \mathrm{C}$ using preheated electronic grills. The core temperature of samples reached $71.1^{\circ} \mathrm{C}$, as measured using a digital thermocouple machine (Tes-1305, Tes Electrical Co., Taipei, Taiwan) equipped with a data logger (RS-232, Tes Electrical Co., Taiwan).

\section{Experiment methods}

The samples $(5 \mathrm{~g})$ were added with $20 \mathrm{~mL}$ of distilled water and homogenized. Then, $\mathrm{pH}$ was measured using a $\mathrm{pH}$ meter (Model 340, Mettler-Toledo GmbH, Schwerzenbach, Switzerland) calibrated with $\mathrm{pH} 4.0,7.0$, and 10.0 solutions. The color properties of samples were determined using a colorimeter (Minolta Chroma meter CR-210, Minolta Ltd., Osaka, Japan, calibrated with a white plate, Commission Internationale de l'Eclairage (CIE) $L^{\star}$ value: 97.83 , CIE $a^{\star}$ value: 0.43 , CIE $b^{*}$ value: $1.98,2^{\circ}$ observer, D65) after blooming for $30 \mathrm{~min}$. We measured the initial sample weight, weight after cooking was measured after the cooked samples were cooled to room temperature $\left(21^{\circ} \mathrm{C}\right)$ for $3 \mathrm{~h}$ and the cooking weight loss was deduced. The WHC was measured using filter paper press as described by Kim et al [10]. After cooking, the six cores per each sample were collected parallel to the muscle fiber shape by using a $1.27 \mathrm{~cm}$ diameter handed coring device, and the shear force (SF) was measured using a TA-XT2 $i$ (Stable Micro System, Scarsdale, NY, USA) equipped with a triangle angular slot cutting edge under a crosshead speed of $1.5 \mathrm{~mm} / \mathrm{s}$. Myofibrillar fragmentation index (MFI) was measured using the method described by Culler et al [11]. Sample protein was extracted using MFI buffer solution (20 $\mathrm{mM}$ potassium phosphate at $\mathrm{pH} 7.0$ with $100 \mathrm{mM} \mathrm{KCl}, 1 \mathrm{mM}$ ethylenediaminetetraacetic acid, $1 \mathrm{mM} \mathrm{NaN}_{3}$, and $1 \mathrm{mM}$ $\left.\mathrm{MgCl}_{2}\right)$. The absorbance of the extract $(0.5 \mathrm{mg}$ protein $/ \mathrm{mL})$ was evaluated at $540 \mathrm{~nm}$ by using a spectrophotometer (Optizen $2120 U V$, Mecasys, Seoul, Korea). The protein degradation and denaturation in meat was evaluated by using the protein extracts $(0.5 \mathrm{mg}$ protein $/ \mathrm{mL}$ ) from the MFI and $12 \%$ sodium dodecyl sulfate-polyacrylamide gel electrophoresis (SDS-PAGE) according to the method described by Kim et al [12]. In vitro gastrointestinal digestion was conducted using specific steps with 4 phases (mouth, gastric, duodenal, and bile juices) as described by Lee et al [13]. The protein digestibility in the cooked beef during simulated human gastrointestinal digestion was measured by the infiltration rates of dialysis tubing and expressed as the percentage of protein concentration inside and outside the dialysis tubing. The protein concentration was measured using Biuret method.

\section{Statistical analysis}

Six muscles per treatment and AMs (control, WA, and DA) were used as experimental units. The complete assessment was performed in triplicates and significant differences among the replicates $(\mathrm{p}<0.05)$ were not observed. The AM was carried as fixed term and replicators and loins were carried as random term. The results were presented as mean values and standard error values in tables. All the statistical analyses were analyzed as completely randomized designs using SPSS Ver. 20.0 (SPSS Inc., Chicago, IL, USA). One-way analysis of variance and Duncan's multiple testes were used to determine the significant differences among treatments $(\mathrm{p}<0.05)$. Cor- 
relation coefficients between the variables such as digestibility, $\mathrm{pH}, L^{*}$-value, $a^{*}$-value, $b^{*}$-value, cooking weight loss, WHC, SF, and MFI were generated using Pearson's correlation coefficient option (SPSS Inc., Chicago, IL, USA).

\section{RESULTS AND DISCUSSION}

Physicochemical properties and in vitro digestibility In beef loins, the effect of AMs on physicochemical properties and in vitro digestibility are shown in the Table 1 . The $\mathrm{pH}$ of control group was lower than that of groups that underwent aging treatments $(\mathrm{p}<0.05)$. The $\mathrm{pH}$ of $\mathrm{DAB}$ was the highest $(p<0.05)$ among the three groups. Aksu et al [14] reported that the increase in $\mathrm{pH}$ during aging process is because of the formation of nitrogen compounds from proteolysis. In agreement with the results reported by Kim et al [6] we observed that the $\mathrm{pH}$ of $\mathrm{DAB}$ was higher than that of WAB. The lightness, redness, and yellowness values of $\mathrm{DAB}$ were lower than those of WAB ( $<<0.05)$, owing to the high $\mathrm{pH}$ and WHC of $\mathrm{DAB}$ [6]. In terms of consumer perceptions, higher redness of meat contributes to the increase in meat colour acceptability. In addition, higher lightness (about 35) demonstrated the positive relation with the consumer colour acceptability [15]. These color changes in aged meat could be negatively attributed to the consumer acceptability. The cooking loss of $\mathrm{DAB}$ was lower than that of WAB $(\mathrm{p}<0.05)$. On the contrary, the WHC of DAB was higher than that of WAB $(\mathrm{p}<0.05)$. The decreased cooking loss and increased WHC of DAB might be because of low moisture content caused by evaporation during DA [16]. The decreased SF of DAB compared to that of WAB is due to the high proteolysis index [1]. The MFI and protein digestibility of $\mathrm{DAB}$ were higher than that of WAB $(p<0.05)$ owing to the high proteolysis. The aging of meat increased the quantity of small peptides in beef after digestion

Table 1. Effect aging methods on $\mathrm{pH}$, color, cooking loss, water holding capacity, shear force, myofibrillar fragmentation index, and digestibility (\%) of beef loins

\begin{tabular}{|c|c|c|c|}
\hline \multirow{2}{*}{ Items } & \multicolumn{3}{|c|}{ Treatments ${ }^{1)}$} \\
\hline & Control & WAB & DAB \\
\hline $\mathrm{pH}$ & $5.49 \pm 0.01^{c}$ & $5.53 \pm 0.01^{b}$ & $5.58 \pm 0.01^{\mathrm{a}}$ \\
\hline$L^{*}$-value & $30.48 \pm 0.87^{a}$ & $28.25 \pm 0.87^{b}$ & $26.99 \pm 0.22^{c}$ \\
\hline$a^{*}$-value & $17.12 \pm 0.26^{a}$ & $15.49 \pm 0.31^{b}$ & $10.84 \pm 0.98^{c}$ \\
\hline$b^{*}$-value & $8.94 \pm 0.36^{\mathrm{a}}$ & $7.41 \pm 0.26^{b}$ & $5.32 \pm 0.63^{c}$ \\
\hline Cooking loss (\%) & $35.52 \pm 0.14^{\mathrm{a}}$ & $33.28 \pm 0.16^{b}$ & $10.62 \pm 1.28^{c}$ \\
\hline WHC (\%) & $22.62 \pm 1.00^{b}$ & $23.99 \pm 0.46^{b}$ & $30.09 \pm 0.62^{\mathrm{a}}$ \\
\hline$S F(N)$ & $9.78 \pm 0.77^{\mathrm{a}}$ & $8.08 \pm 0.35^{b}$ & $7.95 \pm 0.47^{c}$ \\
\hline $\mathrm{MFI}$ & $92.30 \pm 2.56^{c}$ & $116.63 \pm 1.68^{b}$ & $173.86 \pm 2.34^{a}$ \\
\hline Digestibility (\%) & $98.960 \pm 0.001^{c}$ & $98.972 \pm 0.002^{b}$ & $98.980 \pm 0.001^{a}$ \\
\hline
\end{tabular}

WHC, water holding capacity; SF, shear force; MFI, myofibrillar fragmentation index.

1) Control, non-aged beef; WAB, wet-aged beef; DAB, dry-aged beef.

a-c Means within a row with different letters are significantly different $(p<0.05)$. and the consumption of this meat lowers the blood pressure and causes antioxidant effects [17]. The results of proximate composition from the control, WA and DA were shown as moisture $(61.80 \% \pm 1.13 \%, 58.94 \% \pm 1.39 \%$, and $56.73 \% \pm 1.48 \%)$, protein $(34.68 \% \pm 1.28 \%, 35.90 \% \pm 1.29 \%$, and $34.98 \% \pm 1.42 \%)$ and fat $(4.09 \% \pm 0.13 \%, 5.28 \% \pm 0.66 \%$, and $7.42 \% \pm 0.81 \%)$, respectively.

The SDS-PAGE results of protein samples obtained after performing AMs in beef loins is shown in Figure 1. As expected, the aging of beef loins significantly affected the intensity (percentage) of several protein bands (20 to $48 \mathrm{kDa}$ ) compared to those of the control group. Toldra [18] reported that the various peptides obtained from protein breakdown were detected during the processing of dry-cured ham. In particular, the myosin light chain band ( 16 to $27.5 \mathrm{kDa}$ molecular weight) intensity of the $\mathrm{DAB}$ protein samples was higher than that of the control and WAB groups. Claeys et al [19] reported that the SDS-PAGE protein separation patterns displayed a range of 3 to $17 \mathrm{kDa}$ proteins in aged beef.

After performing the AMs in beef loins, the Pearson correlation coefficients among each physicochemical properties according to different $\mathrm{AMs}$ (WAB and $\mathrm{DAB}$ ) are presented in the Table 2 . The in vitro digestibility of WAB was negatively correlated to $\mathrm{pH}, a^{*}$ and $\mathrm{SF}(\mathrm{p}<0.05)$ whereas the digestibility of $\mathrm{DAB}$ showed negatively correlation with $\mathrm{SF}(\mathrm{p}<0.01)$. The $\mathrm{pH}$ of both WAB and $\mathrm{DAB}$ was positively correlated with $a^{*}$ and $b^{*}$. The cooking loss of WAB exhibited a negative

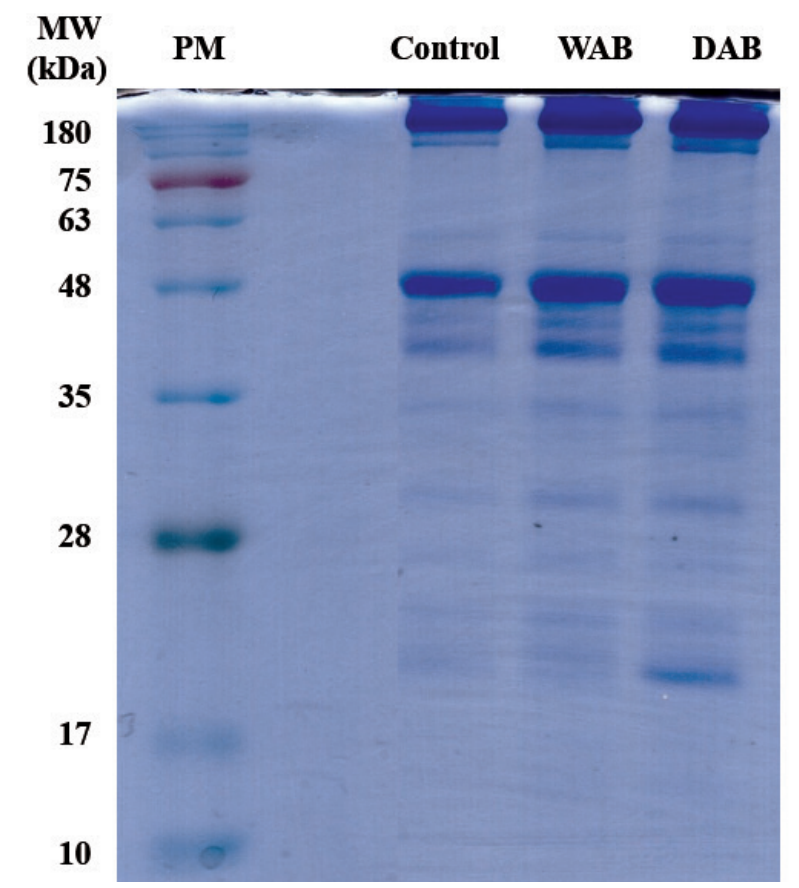

Figure 1. Sodium dodecyl sulfate-polyacrylamide gel electrophoresis patterns of aging methods on beef loin. Vertical numbers indicate molecular weight marker in $\mathrm{kDa}$. PM, protein marker; Control, non-aged beef; WAB, wet-aged beef; DAB, dry-aged beef. 
Table 2. Pearson correlation coefficients and probabilities of aging methods (WAB, DAB) on pH, color, cooking loss, water holding capacity, shear force, myofibrillar fragmentation index, and digestibility (\%) of beef loins

\begin{tabular}{|c|c|c|c|c|c|c|c|c|c|}
\hline Items & Aging methods & $\mathrm{pH}$ & $L^{*}$-value & $a^{*}$-value & $b^{*}$-value & Cooking loss & WHC & SF & MFI \\
\hline \multirow[t]{2}{*}{ Digestibility } & WAB & $-0.632^{*}$ & -0.678 & $-0.883^{* *}$ & -0.705 & -0.037 & -0.083 & $-0.378^{*}$ & 0.478 \\
\hline & $D A B$ & -0.136 & -0.334 & -0.305 & 0.265 & -0.568 & 0.122 & -0.950 ** & 0.428 \\
\hline \multirow[t]{2}{*}{$\mathrm{pH}$} & WAB & 1.000 & 0.692 & $0.876^{*}$ & $0.857^{*}$ & 0.105 & -0.119 & 0.555 & 0.110 \\
\hline & $\mathrm{DAB}$ & 1.000 & -0.515 & $0.897^{* *}$ & $0.877^{* *}$ & 0.200 & 0.352 & -0.312 & -0.542 \\
\hline \multirow{2}{*}{$L^{*}$-value } & WAB & - & 1.000 & 0.672 & $0.874^{*}$ & 0.228 & -0.089 & 0.024 & -0.432 \\
\hline & $D A B$ & - & 1.000 & 0.624 & 0.668 & -0.209 & -0.012 & -0.243 & 0.569 \\
\hline \multirow[t]{2}{*}{$a^{*}$-value } & WAB & - & - & 1.000 & 0.756 & -0.050 & 0.078 & 0.627 & -0.205 \\
\hline & $D A B$ & - & - & 1.000 & $0.982^{* *}$ & -0.267 & -0.336 & 0.379 & 0.392 \\
\hline \multirow[t]{2}{*}{$b^{*}$-value } & WAB & - & - & - & 1.000 & 0.474 & 0.394 & 0.328 & -0.259 \\
\hline & $D A B$ & - & - & - & 1.000 & -0.333 & -0.186 & 0.329 & 0.525 \\
\hline \multirow[t]{2}{*}{ Cooking loss } & WAB & - & - & - & - & 1.000 & $-0.971^{* *}$ & 0.167 & -0.375 \\
\hline & $D A B$ & - & - & - & - & 1.000 & -0.692 & -0.680 & -0.116 \\
\hline \multirow[t]{2}{*}{ WHC } & WAB & - & - & - & - & - & 1.000 & -0.301 & 0.228 \\
\hline & $D A B$ & - & - & - & - & - & 1.000 & -0.114 & -0.329 \\
\hline \multirow[t]{2}{*}{ SF } & WAB & - & - & - & - & - & - & 1.000 & -0.034 \\
\hline & $\mathrm{DAB}$ & - & - & - & - & - & - & 1.000 & -0.034 \\
\hline
\end{tabular}

WAB, wet-aged beef; DAB, dry-aged beef; WHC, water holding capacity; SF, shear force; MFI, myofibrillar fragmentation index.

** Highly significant statistically at $p<0.001 .{ }^{*}$ Highly significant statistically at $p<0.05$.

correlation with WHC. Therefore, a comparison of various physicochemical properties between AMs i.e. WA and DA might provide the information to improve the digestibility and favorable physicochemical properties.

\section{CONCLUSION}

The objectives of this study were to understand the influence of AM on the digestibility and its correlation with physicochemical properties. The in vitro protein digestibility of $\mathrm{DAB}$ slightly improved compared to that of WAB. In vitro digestibility of aged beef was highly $(\mathrm{p}<0.001)$ correlated with all the physicochemical properties except WHC. The correlation coefficient between AMs and WHC was higher than that between AMs and SF $(p<0.05)$ or MFI $(p<0.001)$. The intensity of myosin light chain band (molecular weights from 16 to $27.5 \mathrm{kDa}$ ) of $\mathrm{DAB}$ was higher than that of control and $\mathrm{WAB}$. Although the contribution of the aging process to the taste of the meat was previously reported, the digestibility of comparing dry and wet aged Hanwoo is probably the first approach. Therefore, it concluded that the DA process affected differences of protein digestibility and degradation to contribute to the improvement of meat quality compared to the WAB.

\section{CONFLICT OF INTEREST}

We certify that there is no conflict of interest with any financial organization regarding the material discussed in the manuscript.

\section{ACKNOWLEDGMENTS}

This research was supported by Main Research Program (E0193114-01) of the Korea Food Research Institute (KFRI) funded by the Ministry of Science and ICT (Republic of Korea).

\section{REFERENCES}

1. Hwang YH, Sabikun N, Ismail I, Joo ST. Comparison of meat quality characteristics of wet- and dry-aging pork belly and shoulder blade. Korean J Food Sci Anim Resour 2018;38:9508. https://doi.org/10.5851/kosfa.2018.e27

2. Lee B, Choi YM. Correlation of marbling characteristics with meat quality and histochemical characteristics in longissimus thoracis muscle from hanwoo steers. Food Sci Anim Resour 2019;39:151-61. https://doi.org/10.5851/kosfa.2019.e12

3. Yim DG, Jo C, Mahabbat A, Park JY, Lee SY, Nam KC. Combined effect of aging and irradiation on physicochemical quality of pork shoulder. Food Sci Anim Resour 2019;39:510-9. https:// doi.org/10.5851/kosfa.2019.e46

4. Kim MS, Choe JH, Lee HJ, Yoon YK, Yoon SH, Jo C. Effects of aging and aging method on physicochemical and sensory traits of different beef cuts. Food Sci Anim Resour 2019;39: 54-64. https://doi.org/10.5851/kosfa.2019.e3

5. Smith RD, Nicholson KL, Nicholson JDW, et al. Dry versus wet aging of beef: Retail cutting yields and consumer palatability evaluations of steaks from US Choice and US Select short loins. Meat Sci 2008;79:631-9. https://doi.org/10.1016/ j.meatsci.2007.10.028

6. Kim JH, Jeon MY, Lee CH. Physicochemical and sensory characteristics of commercial, frozen, dry, and wet-aged 
hanwoo sirloins. Asian-Australas J Anim Sci 2019;32:16219. https://doi.org/10.5713/ajas.18.0610

7. Parrish Jr FC, Boles JA, Rust RE, Olson DG. Dry and wet aging effects on palatability attributes of beef loin and rib steaks from three quality grades. J Food Sci 1991;56:601-3. https:// doi.org/10.1111/j.1365-2621.1991.tb05338.x

8. Kim JH, Lee HJ, Shin DM, Kim TK, Kim YB, Choi YS. The dry-aging and heating effects on protein characteristics of beef longissiumus dorsi. Korean J Food Sci Anim Resour 2018;38: 1101-8. https://doi.org/10.5851/kosfa.2018.e43

9. Kim YHB, Kemp R, Samuelsson LM. Effects of dry-aging on meat quality attributes and metabolite profiles of beef loins. Meat Sci 2016;111:168-76. https://doi.org/10.1016/j.meatsci. 2015.09.008

10. Kim TK, Kim YB, Jeon KH, Jang HW, Lee HS, Choi YS. Quality characteristics of Samgyetang according to the sodium chloride level and with/without phosphate in broth. Food Sci Anim Resour 2019;39:102-13. https://doi.org/10.5851/kosfa.2019.e8

11.Culler RD, Parrish Jr FC, Smith GC, Cross HR. Relationship of myofibril fragmentation index to certain chemical, physical and sensory characteristics of bovine longissimus muscle. J Food Sci 1978;43:1177-80. https://doi.org/10.1111/j.13652621.1978.tb15263.x

12. Kim TK, Yong HI, Jeong CH, et al. Technical functional properties of water- and salt-souble protein extracted from edible insects. Food Sci Anim Resour 2019:39:643-54. https://doi. org/10.5851/kosfa.2019.e56

13. Lee S, Jo K, Hur SJ, Choi YS, Kim HJ, Jung S. Low protein digestibility of beef puree in infant in vitro digestion model. Food Sci Anim Resour 2019;39:1000-7. https://doi.org/10. 5851/kosfa.2019.e73

14. Aksu MI, Kaya M, Ockerman HW. Effect of modified atmosphere packaging and temperature on the shelf life of sliced pastirma produced from frozen/thawed meat. J Muscle Foods 2005;16:192-206. https://doi.org/10.1111/j.1745-4573.2005. 08404.x

15. Khliji S, Van de Ven R, Lamb TA, Lanza M, Hopkins DL. Relationship between consumer ranking of lamb colour and objective measures of colour. Meat Sci 2010;85:224-9. https:// doi.org/10.1016/j.meatsci.2010.01.002

16. Obuz E, Akkaya L, Gök V, Dikeman ME. Effects of blade tenderization, aging method and aging time on meat quality characteristics of Longissimus lumborum steaks from cull Holstein cows. Meat Sci 2014;96:1227-32. https://doi.org/10. 1016/j.meatsci.2013.11.015

17. Mora L, Gallego M, Reig M, Toldrá F. Challenges in the quantitation of naturally generated bioactive peptides in processed meats. Trends Food Sci Technol 2017;69:306-14. https://doi. org/10.1016/j.tifs.2017.04.011

18. Toldra F. Proteolysis and lipolysis in flavour development of dry-cured meat products. Meat Sci 1998;49:S101-10. https:// doi.org/10.1016/S0309-1740(98)90041-9

19. Claeys E, De Smet S, Balcaen A, Raes K, Demeyer D. Quantification of fresh meat peptides by SDS-PAGE in relation to ageing time and taste intensity. Meat Sci 2004;67:281-8. https:// doi.org/10.1016/j.meatsci.2003.11.001 